\title{
Macroeconomic Variables and the Kenyan Equity Market: A Time Series Analysis
}

\author{
Cyrus Mutuku \\ Kenya Institute for Public Policy Research and Analysis, Macroeconomics division \\ Mount Kenya University, school of Business and economics, Nairobi, Kenya \\ E-mail: mutukucmm@gmail.com
}

Kirwa Lelei Ng'eny

Kenya Institute for Public Policy Research and Analysis, Macroeconomics division

Economist, Ministry of Mining, Nairobi, Kenya.

E-mail: kirwangeny@gmail.com

Received: October 31, 2014 Accepted: November 16, 2014

doi:10.5296/ber.v5i1.6733 URL: http://dx.doi.org/10.5296/ber.v5i1.6733

\begin{abstract}
The study investigates the dynamic relationship between stock prices and four macroeconomic variables in Kenya using cointegration and vector autoregressive framework. The VAR and VECM analysis reveals that macroeconomic variables drive equity market in the long run. The variables in the VAR model are co integrated with $3.8 \%$ disequilibrium being corrected quarterly. Notably, inflation has a negative effect on equity market suggesting that policy authorities in Kenya should design polices that mitigate inflation for stock market to develop. The results confirm that stock market is not an avenue for perfect hedge against inflation.
\end{abstract}

Keywords: Stock market, VAR, VECM, Macroeconomic variables.

\section{Introduction}

The stock exchange plays a pivotal role in financial intermediation in both developed and developing market by transferring investment funds from surplus to deficit economic units. As the economy grows, more resources are needed to meet the demand generated by business organizations and individual investors. Stock exchange provides businesses, government and individual investors with an avenue to raise capital by selling shares to the investor (Black and 
Gilson, 1998). As an important pillar of the country's economy, the stock market is carefully observed by governmental bodies, companies and investors (Nazir, et al., 2010).

Many emerging economies have had financial liberalization which has led to considerable growth of the stock markets. In addition, more financial markets have become linked together and the risks associated with them are now more interconnected (Bhoyu, 2011). However, both mature and emerging financial markets have had considerable volatility in the past few years. Sudden changes in economic situation can affect investor's perception and decision towards the stock market. This trend is associated with risks attendant to macroeconomic variables in the stock market.

The effects of macroeconomic variables on stock performance have been studied in different economies. Several studies conducted in the US (Fama 1990, Chen et al., 1986, Barro 1990 and Al - Jafari et al., 2011) describe the correlation between US stock return and the aggregate real economic activity. Similarly, Rahman, et al., (2009) studied the long-term effects of selected macroeconomic variables on the Malaysian stock exchange. These studies reveal the significance of domestic macroeconomic variables such as inflation, money supply, currency rate, resources, interest rate, and industrial production as sources of stock market changes. However, majority of the existing studies have entirely focused on the developed countries and other emerging markets. In addition, there is a dearth of literature on the nature of interaction between the equity markets of developing nations and various economic fundamentals based on dynamic models. This study therefore attempts to shed light on how macroeconomic fundamental impacts on the processes of domestic stock market development in Kenya, the largest economy in East Africa and a significant economic power house in the Eastern Africa region.

The present study will also contribute to the literature on stock market and macroeconomic variable linkages for Kenya.

In the next sections, the paper gives an overview on stock market performance in Kenya, and review of related literature. Afterwards, we describe the methodology followed in our study and finally present the results of our empirical analysis and the conclusion.

\section{Stock Market Performance in Kenya}

The NSE was constituted in 1954 as a voluntary association of stockbrokers registered under the Societies Act (NSE, 1997a). It was mandated to develop the stock market and regulate trading activities. The evolutionary process of the NSE can be divided into various developmental stages defined by specific institutional characteristics. Stage one is the initiation period before formalization of share trading (1920s-1953) while stage two (1954-1963) is the period when the market was formalized but before the political independence. The post-independence period which constitutes stage three (1964-1970) was the period before the Government made the first attempt to regulate the operations of the market. During stage four, the Government established the Capital Issue Committee (CIC) as a first attempt to oversee the operations of the stock market, (Ngugi, 2003). NSE has undergone gradual development marked by implementation of automated trading system in 2006, uploading of government 


\section{Ml Macrothink}

Business and Economic Research ISSN 2162-4860 2015, Vol. 5, No. 1

bonds in the automated system in 2009 and becoming a member of the financial information service division of the software and information industry association. Currently, NSE accounts for over $90 \%$ of market activity in the East African region and is a reference point in terms of setting standards for the other markets in the region. As an emerging capital market, it has faced challenges to its development and growth such as economic depression and political uncertainty, among others.

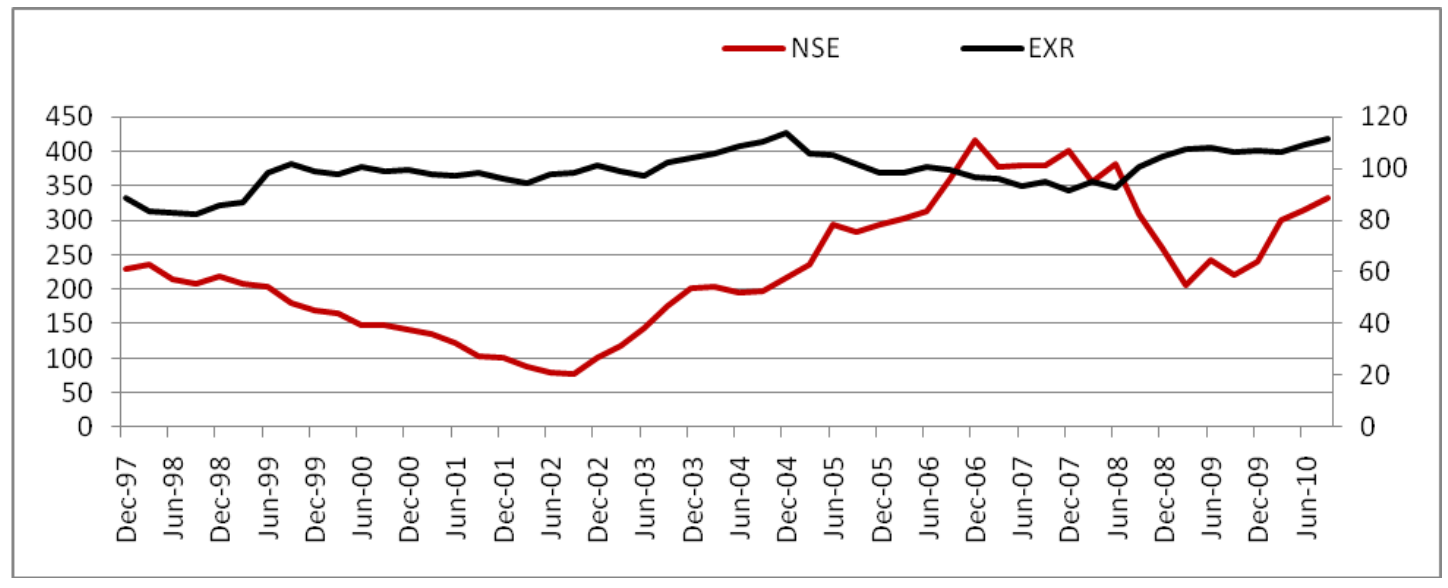

Figure 1. Nairobi stock index-NSE and exchange rate-EXR time trends

Source: Author, 2014

Figure 1 shows a gradual and consistent growth in the index between March 2002 and march 2006 which can be explained by the stable macroeconomic stability that prevailed in the same period. Notably, between June 2008 and March 2009, a drastic down turn was experienced. This can be attributed to the multipronged negative effects of the global financial meltdown and the post-election violence that rocked various parts of Kenya for the same period. This trend was reversed in mid-2009, possibly due to proper macroeconomic policy coordination and stable macro economic variables stability. Over the entire period of study, the exchange rate seems relatively stable.

\subsection{Empirical Overview}

Literature is rich with empirical studies analyzing the relationship between stock market index and macroeconomic variables. Studies reveal strong relationships between macroeconomic variables and stock returns. Fama (1990) stated that expected inflation is negatively associated with the share price. Darrat (1990) found that budget deficits, long term bond rates, the amount of industrial production and the volatility of interest rate have an impact on the stock returns. Achsani and Strohe (2002) examined the relationship between inflation and the index of Jakarta stock exchange and concluded that inflation has a negative relationship with stock exchange index.

Nishat (2004) evaluated the long term association among macroeconomic variables, stock prices and employed money supply, consumer price index (CPI), industrial production index, (IPI) and foreign exchange rate as explanatory variable. Nishat used Karachi stock exchange 100 index price from 1974 to 2004 . Most of the time series data is non-stationary therefore unit 
root technique is used to make data stationary. The result also indicates that industrial production significantly affects macroeconomic variables. Grange causality test was used to find the correlation among the variables. The results show that there are causal relationships among the stock price and macroeconomics variables. However, the results show that interest rate is not granger caused by stock prices.

Gay (2008) evaluated the association among stock prices and macroeconomics variables in cases of China, India, Brazil and Russia. The four are considered to be the emerging economies of the world. The study used oil price, exchange rate, and moving average lags values as explanatory variables. The MA (Moving Average) method with OLS (Ordinary least square) was employed. The study concluded that in emerging economies the domestic factors influence more than external factors i.e. exchange rate and oil prices.

Mukherjee and Naka (1995) investigated the role of macroeconomic variables on the index of Tokyo stock exchange. They found a long-term equilibrium relationship between the index of Tokyo stock exchange and macroeconomic variables such as money supply, exchange rate and long-term bond rate. These findings illuminate those of an earlier study by Chen (1991) which revealed that market excess returns can be predicted by using lagged production growth rate, treasury bill rate, and the term structure.

Apergis and Eleftherio (2002) investigated that the relationship among the index of Athens stock exchange, interest rate and inflation. The study concluded that inflation has greater impact on the performance of the index of Athens stock exchange than interest rate. Rapach (2001) analyzed the long run relationship between inflation and the stock prices. Using macroeconomic data from sixteen developed countries, the study found a weak relationship between inflation and stock prices. Liu ve Shrestha (2008) examined the relationship between a set of macroeconomic variables and the index of Chinese stock market. By employing heteroscedastic cointegration, they found that a significant relationship exists between the index of the Chinese stock market and macroeconomic variables. They concluded that inflation, exchange rate and interest rate have a negative relationship with the index of Chinese stock market.

Hashemzadeh and Durukan (1999) studied the link between macroeconomic variables and the stock prices in Istanbul stock exchange. The empirical results showed that interest rate is negatively associated with the stock price and there is no statistically significant relationship between inflation and stock price.

Aydemir and Demirhan (2009) investigated the relationship between exchange rate and the index of Istanbul stock exchange. By employing Toda-Yamamoto causality test, they found that there exists a two-way causation between stock exchange index and exchange rate.

In an earlier study, Erdem et al., (2005) analyzed the relationship between macroeconomic variables and the index of Istanbul stock exchange. They concluded that there is a negative relationship between inflation and the stock price, and real economic activity proxied by industrial production has a positive effect on the stock price. The result shows that ambiguous affects of exchange rate deprecation on stock prices. 
Mutuku and Kimani (2012) investigated the impact of inflation on Nairobi stock market performance. They used time series data spanning 1996 to 2010 and vector autoregressive based co-integration technique. The study revealed that inflation has a negative effect on NSE hence stock market is not a perfect hedge against inflation. It is evident from past empirical studies that specific macroeconomic variables effect on stock market is not only inconsistent but also non generalizable from one study to another, hence a country specific study using a wider ranges of macroeconomic variables is necessary.

\subsection{Theoretical overview}

\subsubsection{Arbitrage Pricing Theory}

The theoretical underpinning of this study is the arbitrage pricing theory. Arbitrage Pricing Theory is a general theory of asset pricing that has become influential in the pricing of assets. This theory was developed primarily by the economist Stephen Ross in 1976 as an alternative to the capital market pricing model (CAPM). It is a multi-factor model in which every investor believes that the stochastic properties of returns of capital assets are consistent with factors structure. Ross (1976) argues that if equilibrium prices offer no arbitrage opportunities over static portfolio of assets, then the expected returns on the assets are approximately linearly related to the factor loadings or beta. In other words, the expected returns of a financial asset can be modeled as a linear function of various macroeconomic variables or theoretical market indices, where the sensitivity to change in each factor is represented by a factor specific beta coefficient. The model-derived rate of return is used to price the asset correctly and the asset price should equal the expected end of period price discounted at the rate $r$, implied by the model. If the price diverges, arbitrage should bring it back into line. APT can be written in equation 1 below as;

$$
E(r)_{i}=r f+\beta_{i t} F_{i}+\beta_{12} F_{2}+\beta_{13} F_{3}+\ldots+\beta_{i n} F_{n}+\varepsilon_{t}
$$

Where $E\left(r_{i}\right)$ is the risky asset's expected return; $r f$ is the risk free rate; $\beta_{i n}$ is the sensitivity of the asset to factor $n$, also called factor loading; $\mathrm{F}_{\mathrm{n}}$ is the macroeconomic factors and $\varepsilon_{\mathrm{t}}$ in this equation is idiosyncratic risk.

\section{Methodology}

\section{1 Data}

The quarterly data series : nominal gross domestic product-GDP, consumer price index-CPI, Treasury bond rate and Nominal exchange rate-EXR were obtained from the Central Bank of Kenya. The data series spanning 1997 t0 2010 were transformed into natural logarithms.

\subsection{Model Specification and Preliminary Analysis}

In this section we investigate properties of the variables and also specify a dynamic model using the VAR frame work. As a pre-requisite for co-integration analysis we first test for unit roots using the ADF and PP unit roots test. Table 1 below shows that all the variables are non-stationary at levels and stationary at first difference. We proceed to test for long-run 
relationship using Johansen and Juselius (1990) test. Since the test is done in VAR framework, we first establish the optimal lag length for the VAR system. Table 2 shows that Majority of the lag length criteria suggest 4 lags.

Table 1. Test of unit root with intercept and trend

\begin{tabular}{|c|c|c|c|c|}
\hline & \multicolumn{2}{|l|}{ ADF Test } & \multicolumn{2}{|l|}{ PP test } \\
\hline Variables & & & Test statistics & Conclusions \\
\hline \multirow[t]{2}{*}{ LNCPI } & level & -3.5004 & -2.9199 & $\mathrm{I}(1)$ \\
\hline & First Difference & -2.9211 & 2.9199 & $\mathrm{I}(0)$ \\
\hline \multirow[t]{2}{*}{ LNGDP } & level & -3.5085 & -2.9199 & $\mathrm{I}(1)$ \\
\hline & First Difference & -3.5085 & -2.9211 & $\mathrm{I}(0)$ \\
\hline \multirow[t]{2}{*}{ LNTB } & level & -3.5004 & -2.9199 & $\mathrm{I}(1)$ \\
\hline & First Difference & -3.5023 & -2.9211 & $\mathrm{I}(0)$ \\
\hline \multirow[t]{2}{*}{ LNEXR } & level & -3.5085 & -2.9199 & $\mathrm{I}(1)$ \\
\hline & First Difference & -3.5005 & -2.9211 & $\mathrm{I}(0)$ \\
\hline
\end{tabular}

Source: Author, (2014)

Table 2. Optimal lag length selection criterion

\begin{tabular}{|c|c|c|c|c|c|}
\hline Lag & LR & FPE & AIC & SC & HQ \\
\hline 0 & NA & $1.08 \mathrm{e}-10$ & -8.761267 & -8.562502 & -8.686809 \\
\hline 1 & 461.0440 & $3.18 \mathrm{e}-15$ & -19.20041 & $-18.00782 *$ & -18.75366 \\
\hline 2 & 63.77810 & $1.59 \mathrm{e}-15$ & -19.93569 & -17.74927 & -19.11664 \\
\hline 3 & 53.47537 & $8.78 \mathrm{e}-16$ & -20.63124 & -17.45100 & -19.43990 \\
\hline 4 & $48.71310^{*}$ & $4.59 \mathrm{e}-16^{*}$ & -21.49281 & -17.31874 & $-19.92918^{*}$ \\
\hline 5 & 9.869755 & $1.22 \mathrm{e}-15$ & -20.89934 & -15.73144 & -18.96341 \\
\hline 6 & 27.45322 & $1.16 \mathrm{e}-15$ & $-21.64260^{*}$ & -15.48087 & -19.33438 \\
\hline * indicates lag order selected by the criterion & & \\
\hline \\
LR: Sequential modified LR test statistic (each test at 5\% level) \\
\hline
\end{tabular}

Since the test is done in VAR framework, we first establish the optimal lag length for the VAR system. Table 2 shows that Majority of the lag length criteria suggest 4 lags. Then, we use four lags as the optimal lag length for the VAR structure.

Table: 3. Cointegration Test Results

\begin{tabular}{|c|c|c|c|c|}
\hline \multicolumn{5}{|c|}{ Trace statistic } \\
\hline Hypothesized & & Trace & 0.05 & \\
\hline No. of CE(s) & Eigen value & Statistic & Critical Value & Prob.** \\
\hline None * & 0.593270 & 114.6483 & 76.97277 & 0.0000 \\
\hline At most 1 * & 0.515939 & 72.36689 & 54.07904 & 0.0005 \\
\hline
\end{tabular}




\begin{tabular}{|c|c|c|c|c|}
\hline At most $2 *$ & 0.330600 & 38.26635 & 35.19275 & 0.0226 \\
\hline At most 3 & 0.246389 & 19.40181 & 20.26184 & 0.0653 \\
\hline At most 4 & 0.121839 & 6.106509 & 9.164546 & 0.1827 \\
\hline \multicolumn{5}{|c|}{ Trace test indicates 3 co-integrating (s) equations the 0.05 level } \\
\hline \multicolumn{5}{|c|}{$*$ denotes rejection of the hypothesis at the 0.05 level } \\
\hline \multicolumn{5}{|c|}{ Maximum Eigen Statistic } \\
\hline Hypothesized & & Max-Eigen & 0.05 & \\
\hline No. of CE(s) & Eigen value & Statistic & Critical Value & Prob.** \\
\hline None * & 0.593270 & 42.28142 & 34.80587 & 0.0054 \\
\hline At most $1 *$ & 0.515939 & 34.10054 & 28.58808 & 0.0089 \\
\hline At most 2 & 0.330600 & 18.86454 & 22.29962 & 0.1410 \\
\hline At most 3 & 0.246389 & 13.29530 & 15.89210 & 0.1227 \\
\hline At most 4 & 0.121839 & 6.106509 & 9.164546 & 0.1827 \\
\hline \multicolumn{5}{|c|}{ Max-Eigen value test indicates 2 co-integrating equations at the 0.05 level } \\
\hline \multicolumn{5}{|c|}{$*$ denotes rejection of the hypothesis at the 0.05 level } \\
\hline
\end{tabular}

Source: Author, 2014

At a lag length equal 4, the trace statistic indicates the presence of three co-integrating vectors while the maximum Eigen statistic indicates two co-integrating vectors. According to Johansen and Juselius (1990) in case of more than one co-integrating vector, the vector that corresponds to the maximum Eigen value is the most useful. In this case we have 2 co-integrating equations that we need to identify. We followed the procedure suggested by Mansor (2008), and restricting the exchange rate coefficient to zero. The LR test confirms validity of the restriction at $5 \%$ significant level. The co-integrating vector normalized on stock index was estimated as follows:

\section{LNSE=23.1LNGDP+9LNEXR-11LNCPI+0.08TBR+275}

The co integrating vector implies that the long run performance of the equity market in Kenya is positively driven by the overall level of economic activity, exchange rate and the treasury bills. The general price level is negatively impacting on the equity market performance implying that stock market is not a perfect hedge against inflation. Such findings are consistent with the findings of Khil and Lee(2000). Research on the relationship between CPI and stock market performance indicate that an increase in inflation rate leads to an increase in production costs and consequently a decrease in the future cash flow (Maysami and Koh, 2000; Wongbangpo and Sharma, 2002). Such outcomes are likely to decrease the share value, production, and profit of any firm. Since the variables are co integrated, it is possible to have a vector error correction model (VECM) representation as shown below where NSE index is the dependent variable.

Table 4. Error correction model

\begin{tabular}{|c|c|}
\hline \multicolumn{2}{|c|}{ Vector Error Correction Estimates } \\
\hline & D(LNNSE) \\
\hline ECM(-1) & -0.038568 \\
\hline & $(0.04117)$ \\
\hline & {$[-0.93692]$} \\
\hline D(LNNSE(-1)) & 0.346553 \\
\hline
\end{tabular}




\begin{tabular}{|c|c|}
\hline & $(0.17058)$ \\
\hline & [2.03165] \\
\hline \multirow[t]{3}{*}{ D(LNNSE(-2)) } & 0.295863 \\
\hline & $(0.16511)$ \\
\hline & [ 1.79191$]$ \\
\hline \multirow{3}{*}{ D(LNGDP(-1)) } & -0.412134 \\
\hline & $(0.60157)$ \\
\hline & {$[-0.68510]$} \\
\hline \multirow{3}{*}{ D(LNGDP(-2)) } & -0.726837 \\
\hline & $(0.51632)$ \\
\hline & {$[-1.40772]$} \\
\hline \multirow[t]{3}{*}{$\mathrm{D}(\mathrm{LNEXR}(-1))$} & -0.517846 \\
\hline & $(0.67613)$ \\
\hline & {$[-0.76590]$} \\
\hline \multirow[t]{3}{*}{$\mathrm{D}(\mathrm{LNEXR}(-2))$} & 0.180419 \\
\hline & $(0.64775)$ \\
\hline & {$[0.27853]$} \\
\hline \multirow[t]{3}{*}{ D(LNCPI(-1)) } & 0.047331 \\
\hline & $(0.91157)$ \\
\hline & [0.05192] \\
\hline \multirow[t]{3}{*}{ D(LNCPI(-2)) } & 0.676906 \\
\hline & $(0.82429)$ \\
\hline & {$[0.82120]$} \\
\hline \multirow[t]{3}{*}{$\mathrm{D}(\mathrm{TB}(-1))$} & -0.002466 \\
\hline & $(0.00922)$ \\
\hline & {$[-0.26761]$} \\
\hline \multirow[t]{3}{*}{$\mathrm{D}(\mathrm{TB}(-2))$} & 0.001746 \\
\hline & $(0.00910)$ \\
\hline & [ 0.19182$]$ \\
\hline \multirow[t]{3}{*}{$\mathrm{C}$} & 0.002429 \\
\hline & $(0.02840)$ \\
\hline & {$[0.08552]$} \\
\hline \multirow[t]{2}{*}{ R-squared } & \\
\hline & 0.248051 \\
\hline
\end{tabular}

Source, Author, 2014

\section{Conclusion}

The main objective of this study was to investigate the relationship between Nairobi stock market and macroeconomic variables in Kenya. Positive relationships were found between the Nairobi share prices (NSE); the economic growth rate (GDP) exchange rate (EXR) and T-bill rate(TBR). However, the study found a negative relationship between NSE performance and consumer price index (CPI). The short term analysis reveals that the relationship between the variables adjust to equilibrium at a speed of $3.8 \%$ per quarter. The study nullifies the argument that stock market can hedge against inflation. It also suggests that macroeconomic performance largely explains the behavior of equity market in the long run. The findings imply that policy authorities should put stringent measures to curb inflation and also promote macroeconomic stability. In these regard, fiscal and monetary policies should be designed to have automatic stabilization effect. Automatic stabilization ensures macroeconomic stability and eradicates adverse effects of instability associated with discretionary policy lags. 


\section{References}

Aggarwal, R. (1981). Exchange Rates and Stock Prices, A Study of the US Capital Markets underFloating Exchange Rates, Akron Business and Economic Review, 12(4), 7-12.

Apergis, N., Eleftheriou, S. (2002). Interest Rates, Inflation and Stock Prices: The Case of Athens Stock Exchange, Journal of Policy Modeling, 24, 231-236. http://dx.doi.org/10.1016/S0161-8938(02)00105-9

Aydemir, O., \& Demirhan, E. (2009). The Relationship between Stock Prices and Exchange Rates:Evidence from Turkey, International Research Journal of Finance and Economics, 23, 207-215.

Barro, R. J. (1990). The stock market and investment. Review of Financial Studies, 3, 115-131. http://dx.doi.org/10.1093/rfs/3.1.115

Bhoyu, P. (2011). Macroeconomic relationship in Indonesia stock market. Evidence on Cointegration: Georgia state university

Black, B. S., \& Gilson, R. J. (1998), Venture Capital and the Structure of Capital Markets: Banks versus Stock Markets, Journal of Financial Economics, 47(3), 243-277. http://dx.doi.org/10.1016/S0304-405X(97)00045-7

Chen, N. F. (1991). Financial Investment Opportunities and the Macro economy, Journal of Finance, 16(2), 529-553. http://dx.doi.org/10.1111/j.1540-6261.1991.tb02673.x

Darrat, A. F. (1990). Stock Returns, Money and Fiscal Policy, Journal of Financial and Quantitative Analysis, 25(3), 387-398. http://dx.doi.org/10.2307/2330703

Durukan, B. (1999). Istanbul Menkul Kiymetler Borsasında Makroekonomik Değiskenlerin HisseSenedi Fiyatlarına Etkisi, IMKB Dergisi, 3(11), 19-39.

Erdem C., Arslan C. K., \& Erdem M. S. (2005). Effects of Macroeconomic Variables on Istanbul Stock Exchange Indexes, Applied Financial Economics, 15, 987-994. http://dx.doi.org/10.1080/09603100500120365

Fama, E. F., (1990). Stock returns, expected returns, and real activity. Journal of Finance 45, 1089-1108.Floros, C. (2008). Modeling volatility using GARCH models: evidence from Egypt and Israel. Middle Eastern Finance and Economics, 2, 31-41.

Gay, R. (2008) Effect Of Macroeconomic Variables On Stock Market Returns For Four Emerging Economies: Brazil, Russia, India, And China : international finance and economic journal

Hashemzadeh, N., \& Taylor, P. (1988).Stock Prices, Money Supply, and Interest Rates: The Question of Causality, Applied Economics, 20(12), 1603-1611. http://dx.doi.org/10.1080/00036848800000091

Khil, J., \& Lee, B. S. (2000). Are comman stocks a good hedge against inflation? Evidence from the Pasific-rim countries, Pasific-Basin Finance Journal. 8(3-4), 457-482. 
http://dx.doi.org/10.1016/S0927-538X(00)00019-6

Liu, M. H., \& Shrestha, K. M. (2008). Analysis of the Long-Term Relationship between Macroeconomic Variables and the Chinese Stock Market using Heteroscedastic Cointegration, Managerial Finance, 34(11), 744-755. http://dx.doi.org/10.1108/03074350810900479

Maysami, R. C., \& Koh, T. S. (2000), A Vector Error Correction model of the Singapore stock market, International Review of Economics and Finance, 9(1), 79-96. http://dx.doi.org/10.1016/S1059-0560(99)00042-8

Mukherjee, T., \& Naka, A. (1995). Dynamic Linkage Between Macroeconomic Variables and the Japanese Stock Market: An Application of a Vector Error Correction Model, Journal of Financial Research, 18, 223-237. http://dx.doi.org/10.1111/j.1475-6803.1995.tb00563.x

Mutuku, c. m., \& kimani, D. k. (2012). Inflation dynamics on the overall stock market performance. The case of Nairobi Securities exchange in Kenya. Economics and Finance Review.

Nazir, M. S., Nawaz, M. M., \& Gilani, U. J. (2010). Relationship between Economic Growth and Stock Market Development, African Journal of Business Management, 4(16), 3473-3479.

Nishat, M., \& Shaheen, R. (2004). Macroeconomic Factors and Pakistani Equity Market, The Pakistan Development Review, 43(4), 619-637.

Ngugi, R. A. (2003). Development of stock exchange. A historical perspective. Kenya institute for public policy research and analysis. Working paper No.27.

Rapach, D. E. (2001). The Long-Run Relationship Between Inflation and Real Stock Prices, Journal of Macroeconomics, 24, 331-351. http://dx.doi.org/10.1016/S0164-0704(02)00041-1

Wongbangpo, P, \& Sharma, S. C. (2002). Stock Market and Macroeconomic Fundamental Dynamic Interaction: ASEAN-5 Countries. Journal of Asian Economics, 13(1), 27-51. http://dx.doi.org/10.1016/S1049-0078(01)00111-7

\section{Copyright Disclaimer}

Copyright for this article is retained by the author(s), with first publication rights granted to the journal.

This is an open-access article distributed under the terms and conditions of the Creative Commons Attribution license (http://creativecommons.org/licenses/by/3.0/). 